\title{
Pengaruh Iklan terhadap Perilaku Merokok Siswa: Literature Review
}

\author{
Rofiatul Hasanah, Rara Warih Gayatri*, Suci Puspita Ratih \\ Universitas Negeri Malang, Jl. Semarang No. 5 Malang, Jawa Timur, Indonesia \\ *Penulis korespondensi, Surel: rara.warih.fik@um.ac.id
}

Paper received: 1-10-2021; revised: 19-10-2021; accepted: 25-10-2021

\begin{abstract}
The prevalence of adolescent tobacco users in Indonesia continues to increase, while on the other hand the marketing of cigarettes through advertising is still often found. This Literature review aims to find out the results of previous research on the influence of advertising on smoking behavior of junior high school students in Indonesia for the last 10 years. The research method used is literature review by following the flow diagram of the Preferred Reporting Items for Systematic Reviews and Meta-Analyzes (PRISMA) as well as the help of Axis Tools as a Critical Appraisal. The result of this literature review, 7 out of 9 articles reviewed stated a significant influence between cigarette advertising and student smoking behavior. The domain of targeted behavior is practice, including the act of trying cigarettes for the first time as well as the formation of perceptions about cigarettes in accordance with the description of the ad. It can be concluded that the influence of exposure to the ads is directly proportional to the smoking behavior of high school students in Indonesia.
\end{abstract}

Keywords: cigarette advertisement; smoking behavior; teenager; tobacco promotion; tobacco sponsorship

\begin{abstract}
Abstrak
Prevalensi pengguna tembakau usia remaja di Indonesia terus meningkat, sedang di sisi lain pemasaran rokok melalui iklan masih sering ditemukan, Literature review ini bertujuan untuk mengetahui hasil penelitian terdahulu mengenai pengaruh iklan terhadap perilaku merokok siswa sekolah menengah pertama di Indonesia selama 10 tahun terakhir. Metode penelitian yang digunakan ialah kajian pustaka dengan mengikuti diagram alir Preferred Reporting Items for Systematic Reviews and Meta-Analyzes (PRISMA) serta bantuan Axis Tools sebagai Critical Appraisal. Hasil yang didapatkan dari literature review ini, 7 dari 9 artikel yang dikaji menyatakan adanya pengaruh signifikan antara iklan rokok dengan perilaku merokok siswa. Domain perilaku yang disasar ialah praktik, termasuk adanya tindakan mencoba rokok untuk pertama kali serta terbentuknya persepsi mengenai rokok yang sesuai dengan gambaran iklan. Dapat disimpulkan bahwa pengaruh paparan iklan berbanding lurus dengan adanya perilaku merokok siswa sekolah menengah pertama di Indonesia.
\end{abstract}

Kata kunci: iklan rokok; perilaku merokok; remaja; promosi rokok

\section{Pendahuluan}

Berdasarkan paparan World Health Organization (WHO) pada tahun 2020, terdapat delapan juta korban jiwa akibat penyakit yang diakibatkan oleh kebiasaan merokok. 600 ribu orang meninggal dunia hanya karena menghirup asap rokok (Oddo et al., 2019). Sementara itu, di Indonesia angka mortalitas akibat penggunaan tembakau mencapai 217 ribu jiwa (TCSC IAKMI, 2018).

Prevalensi perilaku pengguna tembakau secara Nasional terus mengalami peningkatan, hingga pada tahun 2018 mencapai angka 33,8\% (Kemenkes RI, 2019). Dari total penduduk Indonesia yang mengkonsumsi tembakau, 9,1\% diantaranya adalah remaja berusia 10-18 
tahun (Kemenkes RI, 2019), dimana usia 13-15 tahun merupakan periode dimana paling sering ditemukan remaja yang mencoba rokok untuk pertama kalinya (World Health Organization, 2014).

Remaja Indonesia merupakan sasaran utama pemasaran rokok melalui berbagai media, termasuk iklan (Astuti et al., 2020; Prabandari \& Dewi, 2016; TCSC IAKMI, 2018). Pendekatan melalui media iklan terbukti efektif menjadi pemicu remaja mulai mengkonsumsi rokok. Menurut Henriksen (2012), dampak persuasif iklan sangatlah nyata dan berpengaruh signifikan terhadap mereka yang terpapar. Sayangnya, pemerintah Indonesia belum mampu menindak secara tegas larangan peredaran iklan rokok (Fajar, 2021; Ilmaskal et al., 2017; TCSC IAKMI, 2018).

Tujuan dari literature review ini adalah mengetahui pengaruh iklan rokok terhadap perilaku merokok siswa sekolah menengah pertama di Indonesia, mengingat adanya peningkatan konsumsi rokok, pengaruh persuasif iklan pada remaja, serta keberadaan regulasi yang belum mampu melindungi remaja dari terpaan iklan.

\section{Metode}

Desain penelitian yang digunakan adalah literature review atau kajian pustaka. Pencarian artikel dilakukan pada lima database, yakni Proquest sebagai penyedia akses jurnal berskala Internasional, Science and Technology Index (Sinta) sebagai penyedia akses jurnal berskala nasional, dan Google Scholar, PubMed, serta Wiley sebagai sumber tambahan. Artikel yang diperlukan berasal dari publikasi ilmiah selama 10 tahun terakhir, dengan keyword berbahasa Indonesia dan berbahasa Inggris. Kriteria inklusi dan eksklusi dibentuk berdasarkan populasi, intervensi, komparasi, dan hasil akhir (PICOS Framework). Pada proses uji kelayakan digunakan bantuan Axis Tools sebagai critical appraisal tool. Sedangkan pada proses analisis data akan dilaksanakan dengan metode analisis deskriptif naratif.

\section{Hasil dan Pembahasan}

Hasil pencarian awal artikel menjangkau 1461 artikel hingga pada tahap akhir hanya menyisakan 9 artikel. Kesembilan artikel memiliki persamaan berupa variabel yang diteliti, tujuan penelitian, metode penelitian dan negara letak penelitian dilangsungkan.

Selain itu, kesembilan artikel juga memiliki beberapa perbedaan. Diantaranya ialah tahun terbit serta bahasa yang digunakan. Satu artikel diterbitkan pada tahun 2013, dua artikel pada tahun 2014, satu artikel pada tahun 2016, kemudian pada tahun 2017 didapat dua artikel, 2019 terdapat satu artikel, serta pada tahun 2020 ditemukan 1 artikel, dan tahun 2021 sebanyak 1 artikel. Sedangkan penggunaan bahasa pada artikel didapatkan bahwa 6 artikel menggunakan dua bahasa (Bahasa Indonesia dan Bahasa Inggris) pada bagian abstrak dan 3 artikel full English. Berikut merupakan rangkuman desain dan analisis statistik yang digunakan pada kesembilan artikel. 
Tabel 1. Hubungan antar Variabel

\begin{tabular}{|c|c|c|c|c|}
\hline \multirow{2}{*}{$\begin{array}{l}\text { Penulis } \\
\text { dan Tahun }\end{array}$} & \multicolumn{2}{|r|}{ Iklan } & \multirow{2}{*}{$\begin{array}{l}\text { Perilaku Merokok } \\
\text { (Praktik) }\end{array}$} & \multirow{2}{*}{$\begin{array}{c}\text { Pengaruh Iklna } \\
\text { terhadap Perilau } \\
\text { (Praktik) Merokok }\end{array}$} \\
\hline & Jenis & Paparan & & \\
\hline $\begin{array}{l}\text { (Rachmat, } \\
\text { dkk., 2013 ) }\end{array}$ & $\begin{array}{l}\text { Televisi \& } \\
\text { Billboard }\end{array}$ & $\begin{array}{l}\text { Dari } 471 \text { siswa, 95\% (448) diantaranya } \\
\text { terpapar }\end{array}$ & $\begin{array}{l}23,2 \%(119) \text { siswa memiliki perilaku merokok (menjadi } \\
\text { perokok). }\end{array}$ & $p$-value $=0,0000$ \\
\hline $\begin{array}{l}\text { (Liem, } \\
2014)\end{array}$ & $\begin{array}{l}\text { Televisi, } \\
\text { billboard, } \\
\text { radio, \& } \\
\text { Point of } \\
\text { Sale }\end{array}$ & $\begin{array}{l}\text { Dari } 390 \text { reponden paparan sebagai berikut } \\
95 \% \text { (366) terpapar iklan telivisi } \\
68 \%(261) \text { terpapar iklan billboard } \\
33 \%(77) \text { terpapar iklan radio } \\
14 \% \text { (55) terpapar iklan point of sale. }\end{array}$ & $\begin{array}{l}\text { Dari } 390 \text { responden ditemui dua praktik merokok yang } \\
\text { diteliti: } \\
36 \%(139) \text { pernah mencoba rokok } \\
10 \%(39) \text { diantaranya menjadi perokok tetap. }\end{array}$ & $\begin{array}{l}P \text {-value iklan terhadap } \\
\text { praktik merokok: } \\
\text { Iklan televisi }=0,837 \\
\text { (mencoba rokok), 0,516 } \\
\text { (menjadi perokok tetap). } \\
\text { Iklan Billboard }=0,298 \\
\text { (mencoba rokok), 0,040 } \\
\text { (menjadi perokok tetap) } \\
\text { Iklan radio }=0,222 \\
\text { (mencoba merokok), } \\
0,079 \text { (menjadi perokok } \\
\text { tetap). } \\
\text { Iklan melalui point of } \\
\text { Sales }=0,818 \text { (mencoba } \\
\text { rokok), } 0,272 \text { (menjadi } \\
\text { perokok tetap). }\end{array}$ \\
\hline $\begin{array}{l}\text { (Wiryanath } \\
\text { a \&, Ani, } \\
2014 \text { ) }\end{array}$ & $\begin{array}{l}\text { Iklan } \\
\text { Televisi }\end{array}$ & $\begin{array}{l}\text { Dari } 75 \text { responden, 92\% (69) diantaranya } \\
\text { terpapar }\end{array}$ & $\begin{array}{l}\text { Dari } 75 \text { responden } 25 \% \text { (17) diantaranya memiliki } \\
\text { perilaku merokok (menjadi perokok). }\end{array}$ & Nilai $p$-value $=0,016$ \\
\hline $\begin{array}{l}\text { Prabandari } \\
\text { \& Dewi, } \\
2016)\end{array}$ & $\begin{array}{l}\text { Billboard, } \\
\text { Banner, } \\
\text { Televisi }\end{array}$ & $\begin{array}{l}66 \% \text { (513) responden terpapar dalam } \\
\text { intensitas rendah (dalam hal ini responden } \\
\text { dijadikan acuan pengukuran } \\
34 \% \text { (265) terpapar dalam intensitas tinggi }\end{array}$ & $\begin{array}{l}21 \%(163) \text { responden menjadi perokok } \\
\text { Tetap. Hal ini dipengaruhi oleh: } \\
56 \%(436) \text { responden mempunyai persepsi bahwa iklan } \\
\text { rokok menargetkan anak muda } \\
32 \%(249) \text { responden mempunyai persepsi bahwa iklan } \\
\text { rokok dapat memengaruhi anak muda untuk merokok }\end{array}$ & $\begin{array}{l}\text { Terpapar iklan rokok } \\
\text { intensitas tinggi dengan } \\
\text { menjadi perokok }=P- \\
\text { value }<0,001, \text { Nilai OR } \\
1,59 \\
\text { yang dipengaruhi oleh: } \\
\text { Persepsi mengenai iklan } \\
\text { rokok menargetkan anak } \\
\text { muda dengan hasil }=P-\end{array}$ \\
\hline
\end{tabular}




\begin{tabular}{|c|c|c|c|c|}
\hline \multirow{2}{*}{$\begin{array}{l}\text { Penulis } \\
\text { dan Tahun }\end{array}$} & \multicolumn{2}{|r|}{ Iklan } & \multirow{2}{*}{$\begin{array}{l}\text { Perilaku Merokok } \\
\text { (Praktik) }\end{array}$} & \multirow{2}{*}{$\begin{array}{c}\text { Pengaruh Iklna } \\
\text { terhadap Perilau } \\
\text { (Praktik) Merokok }\end{array}$} \\
\hline & Jenis & Paparan & & \\
\hline & & & & $\begin{array}{l}\text { value }<0.001, \text { Nilai OR } \\
2,09 \\
\text { Persepsi bahwa iklan } \\
\text { rokok dapat } \\
\text { memengaruhi anak } \\
\text { muda untuk merokok } \\
\text { dengan hasil = P-value } \\
<0,001, \text { Nilai OR } 20,26\end{array}$ \\
\hline $\begin{array}{l}\text { (Purnaningr } \\
\text { um, } \\
\text { Dkk., 2017) }\end{array}$ & $\begin{array}{l}\text { Televisi \& } \\
\text { Internet }\end{array}$ & $\begin{array}{l}58 \%(58) \text { responden terpapar berat } \\
42 \%(42) \text { responden terpapar ringan. }\end{array}$ & $\begin{array}{l}\text { Dari } 100 \text { responden, } 46 \%(46) \text { diantaranya adalah } \\
\text { perokok ringan, sedang } 54 \% \text { (54) sisanya adalah perokok } \\
\text { berat. }\end{array}$ & Nilai $p$-value ialah 0,006 \\
\hline $\begin{array}{l}\text { (Isa, dkk., } \\
\text { 2017) }\end{array}$ & Televisi & $\begin{array}{l}\text { 18\% (18) terpapar iklan rokok } \\
82 \%(82) \text { tidak terpapar }\end{array}$ & $\begin{array}{l}38 \%(38) \text { responden menjadi perokok sedangkan } 62 \% \\
(62) \text { tidak merokok. }\end{array}$ & Nilai $p$-value $=0,791$ \\
\hline $\begin{array}{l}\text { (Utami \& } \\
\text { Susilowati, } \\
\text { 2019) }\end{array}$ & Televisi & $\begin{array}{l}96 \% \text { (128) terpapar } \\
4 \% \text { (6) siswa tidak terpapar }\end{array}$ & $\begin{array}{l}72,4 \% \text { (97) Responden adalah perokok dan } 26,6 \% \text { (37) } \\
\text { tidak merokok. }\end{array}$ & Nilai $p$-value $=0,539$ \\
\hline $\begin{array}{l}\text { (Rizki, dkk., } \\
\text { 2020) }\end{array}$ & Internet & $\begin{array}{l}\text { Dengan jumlah sampel sebesar } 110 \\
\text { responden, } \\
57 \%(63) \text { terpapar } \\
43 \%(47) \text { tidak terpapar }\end{array}$ & $\begin{array}{l}\text { siswa yang merokok sebanyak 43\% (47) dan yang } \\
\text { tidak merokok 57\% (63) orang. }\end{array}$ & Nilai $p$-value $=0,000$ \\
\hline $\begin{array}{l}\text { (Handayani, } \\
\text { dkk., 2021) }\end{array}$ & $\begin{array}{l}\text { Billboard } \\
\text { \& Banner }\end{array}$ & $\begin{array}{l}\text { Paparan kepadatan iklan: 40\% (104) } \\
\text { terpapar ringan, 30\% (78) terpapar } \\
\text { medium, 30\% (78) terpapar berat. } \\
\text { Paparan kedekatan iklan (ditemukan } \\
\text { minimal satu iklan dalam radius } 200 \mathrm{~m} \text { di } \\
\text { sekitar sekolah): } 60 \% \text { (156) terpapar oleh } \\
\text { iklan dan 40\% (104) tidak terpapar oleh } \\
\text { iklan. }\end{array}$ & $\begin{array}{l}\text { 65\% (169) pernah merokok, 35\% (91) tidak pernah } \\
\text { merokok }\end{array}$ & $\begin{array}{l}\text { Nilai OR ialah sebagai } \\
\text { berikut: } \\
\text { Paparan kepadatan } \\
\text { iklan: terpapar medium } \\
\text { dengan nilai OR = } 1,76 \\
\text { dan terpapar berat } \\
\text { dengan nilai OR = 1,93. } \\
\text { Paparan kedekatan iklan } \\
\text { dengan sekolah } \\
\text { menghasilkan nilai OR = } \\
0,68\end{array}$ \\
\hline
\end{tabular}


Tindakan atau Praktik pada penelitian yang dianalisis dapat ditinjau lebih jauh pada kesembilan artikel. Berdasarkan paparan Liem (2014) dan Rizki, dkk. (2020), variabel perilaku merokok yang diteliti berkaitan dengan tindakan mencoba rokok. Sedangkan penelitian Prabandari \& Dewi (2016), variabel perilaku yang diteliti lebih ke arah persepsi yang dimiliki oleh responden. Secara keseluruhan ketujuh artikel menyatakan adanya hubungan antara iklan dan perilaku merokok (Handayani et al., 2021; Liem, 2014; Prabandari \& Dewi, 2016; Purnaningrum et al., 2017; Rachmat et al., 2013; Rizki et al., 2020; Wiryanatha \& Ani, 2014). Sebaliknya 2 hasil penelitian terkait domain praktik menunjukkan hasil berbeda yaitu tidak ditemukannya pengaruh antara iklan rokok dengan praktik merokok (Isa et al., 2017; Utami \& Susilowati, 2019).

\subsection{Adanya Pengaruh Iklan terhadap Praktik}

7 dari 9 artikel yang dianalisis menyatakan terdapat hubungan antara iklan rokok dengan perilaku merokok siswa sekolah menengah pertama Hal tersebut sejalan dengan temuan literature review yang pernah ada sebelumnya di Indonesia. Literature review tersebut menyatakan bahwa $90 \%$ artikel yang diteliti menemukan adanya pengaruh signifikan yang berasal dari lingkungan sekitar, yaitu iklan rokok (Rukmi, 2019).

Sintesis literature review pada bab sebelumnya menyebutkan bahwa hasil penelitian Liem (2014), Prabandari \& Dewi (2016), dan Rizki, dkk. (2020) menemukan adanya kaitan antara iklan rokok dengan tindakan (mencoba) merokok serta persepsi responden. Dapat diartikan bahwa ada kaitan antara iklan rokok dengan praktik. Adanya ketiga temuan sejalan dengan beberapa penelitian sebelumnya. Terpaan iklan memiliki pengaruh terhadap tindakan pengguna sebuah produk berupa barang (Nukuhehe, 2017) hingga sebuah brand jasa (Aruan et al., 2016). Pengaruhnya pun terhitung cukup tinggi (Aruan et al., 2016; Nukuhehe, 2017).

Sebagai tambahan, sebuah penelitian menyebutkan bahwa iklan dapat memicu tindakan (praktik) berupa pembelian suatu produk secara cepat dan bertahan untuk waktu yang lama (Dewi et al., 2012). Perlu kita ketahui bahwa praktik merupakan tingkatan paling akhir dari teori perubahan perilaku (Notoatmodjo, 2012). Apabila sebuah tindakan (praktik) telah berlangsung, dapat dikatakan telah terjadi perubahan perilaku pula (Notoatmodjo, 2016).

Penelitian di beberapa negara maju di dunia, seperti Amerika Serikat, Jerman, Inggris, dan Spanyol menyebutkan bahwa remaja non-perokok yang mendapatkan paparan iklan rokok memiliki kecenderungan yang lebih tinggi untuk mencoba rokok hingga menjadi perokok tetap (ASH.org, 2015; Pierce et al., 2018). Lebih lanjut, sebuah penelitian di India menemukan bahwa remaja yang dalam kesehariannya dapat melihat iklan rokok, baik di sekitar rumah, sekolah, maupun jalanan yang sering dilalui memiliki kecenderungan 2 kali lipat lebih tinggi untuk menjadi perokok dibandingkan remaja yang tidak berkaitan langsung dengan iklan rokok dalam kesehariannya (Mistry et al., 2015). Umumnya pengaruh iklan rokok terhadap perilaku pada negara berkembang memiliki kecenderungan lebih tinggi dibanding pada negara maju, hal ini ditengarai oleh faktor regulasi yang kurang memadai (Mistry et al., 2015).

Paparan iklan baik intensitas, durasi ataupun frekuensi dari iklan berpengaruh pada perilaku merokok siswa. Sesuai dengan hasil Purnaningrum, et al. (2017) menyatakan bahwa responden yang terpapar iklan rokok dengan intensitas berat memiliki kecenderungan 23 kali lebih besar menjadi pecandu rokok berat dibanding mereka yang terpapar rokok dengan 
intensitas ringan. Selain itu, responden yang terpapar dengan intensitas tinggi memiliki kecenderungan 1,5 kali lebih tinggi berniat merokok dan menjadi perokok tetap dibanding mereka yang terpapar dengan intensitas rendah (Purnaningrum et al., 2017).

Faktor kepadatan iklan rokok di sekitar tempat pendidikan dan tempat tinggal juga berperan besar dalam pembentukan perilaku merokok siswa. Sesuai dengan hasil Handayani, et al. (2021), siswa yang lokasi sekolahnya dipadati oleh iklan rokok memiliki kecenderungan 2 kali lebih besar menjadi perokok dibanding mereka yang bersekolah di area yang kepadatan iklannya relatif rendah. Hal ini sejalan dengan penelitian yang dilaksanakan di Kota Padang, meningkatnya iklan rokok berpengaruh pada peningkatan prevalensi perokok usia remaja (Syafrawati et al., 2016).

\subsection{Tidak adanya Pengaruh Iklan terhadap Praktik}

Selain 7 artikel yang menyatakan adanya pengaruh iklan terhadap perilaku merokok, terdapat, 2 dari 9 artikel memperoleh hasil yang berbeda. Pada penelitian Isa, et al. (2017) dan Utami \& Susilowati (2019), didapatkan tidak adanya hubungan yang signifikan antara iklan rokok dengan perilaku merokok remaja. Hal tersebut dapat terjadi dikarenakan adanya faktor lain yang lebih kuat berpengaruh pada perilaku merokok siswa.

Penelitian Isa, et al. (2017) menjadikan variabel kepribadian, orang tua dan saudara, serta peran teman sebaya sebagai variabel bebas selain variabel iklan. Variabel bebas lain inilah yang berpengaruh lebih besar terhadap perilaku, khususnya sikap responden dibanding iklan (Isa et al., 2017). Sedangkan Utami \& Susilowati (2019) menggunakan peran keluarga dan peran teman sebaya sebagai variabel bebas selain variabel iklan. Kedua variabel bebas lainlah yang menjadi prediktor lebih kuat dalam pembentukan perilaku merokok responden pada penelitian ini (Utami \& Susilowati, 2019).

\section{Simpulan}

Berdasarkan sintesis literature review yang dilakukan, 7 dari 9 artikel menemukan adanya pengaruh antara iklan dengan perilaku merokok, khususnya domain praktik. Iklan memengaruhi persepsi mengenai rokok hingga adanya kegiatan mencoba rokok untuk pertama kalinya. Selain itu, pada literature review ini juga ditemukan bahwa faktor kepadatan iklan serta paparan iklan juga berperan dalam menentukan ada tidaknya pengaruh siginfikan terhadap perilaku merokok siswa sekolah menengah pertama di Indonesia.

\section{Daftar Rujukan}

Aruan, D. A., Putri, Y. R., \& Mahadian, A. B. (2016). Pengaruh Persepsi Iklan Televisi Traveloka Versi "tiket Hotel” Terhadap Tindakan Pembelian Pada Komunitas Backpacker Indonnesia Regional Bandung | Aruan | eProceedings of Management. E-Proceeding of Management, 3(1), 76.

ASH.org. (2015). UK Tobacco Advertising and Promotion. Ash.Org, 2002(August 2015), 6. http://ash.org.uk/files/documents/ASH_124.pdf

Astuti, P. A. S., Assunta, M., \& Freeman, B. (2020). Why is tobacco control progress in Indonesia stalled? - a qualitative analysis of interviews with tobacco control experts. BMC Public Health, 20, 1-12. https://doi.org/http://dx.doi.org/10.1186/s12889-020-08640-6

Dewi, N. K., Andri, G., \& Yonaldi, S. (2012). Pengaruh iklan, citra merek, dan kepuasan konsumen terhadap loyalitas konsumen dalam menggunakan vaseline hand and body lotion di kota padang (studi kasus di pt. unilever cabang padang ). Progress in Clinical and Biological Research, 219, 187-210.

Fajar, F. I. D. (2021). Studi implementasi kebijakan kawasan tanpa rokok pada fasilitas pelayanan kesehatan di kabupaten bungo. Jurnal Administrasi Nusantara, 3(2), 52-61. https://doi.org/10.51279/jan.v3i2.369 
Handayani, S., Rachmani, E., Saptorini, K. K., Manglapy, Y. M., Nurjanah, Ahsan, A., \& Kusuma, D. (2021). Is youth smoking related to the density and proximity of outdoor tobacco advertising near schools? Evidence from Indonesia. International Journal of Environmental Research and Public Health, 18(5), 1-8. https://doi.org/10.3390/ijerph18052556

Henriksen, L. (2012). Comprehensive tobacco marketing restrictions: Promotion, packaging, price and place. In Tobacco Control (Vol. 21, Issue 2, pp. 147-153). BMJ Publishing Group Ltd. https://doi.org/10.1136/tobaccocontrol-2011-050416

Ilmaskal, R., Suryo Prabandari, Y., Agung Wibowo, T., Perilaku Kesehatan, D., Kedokteran Sosial, D., Kedokteran, F., Gadjah Mada, U., \& Laboratorium Kesehatan Yogyakarta, B. (2017). Evaluasi penerapan kebijakan peraturan daerah kawasan tanpa rokok di kota Padang Panjang Evaluation of the implementation of the regional regulation of smoke free areas in Padang Panjang city. In Journal.Ugm.Ac.Id. https://journal.ugm.ac.id/bkm/article/view/11716

Isa, L., Lestrai, H., \& Afa, J. R. (2017). Hubungan Tipe Kepribadian, Peran Orang Tua dan Saudara, Peran Teman Sebaya, dan Peran Iklan Rokok dengan Perilaku Merokok pada Siswa Smp Negeri 9. JIMKESMAS, 2(7).

Kemenkes RI. (2019). Hasil Riset Kesehatan Dasar Tahun 2018. Kementrian Kesehatan RI, 53(9), 1689-1699.

Liem, A. (2014). Influences of Mass Media, Family, and Friends Towards Adolescents' Smoking in Yogyakarta (Junior High School). Makara Hubs-Asia, 18(1), 41-52.

Mistry, R., Pednekar, M., Pimple, S., Gupta, P. C., McCarthy, W. J., Raute, L. J., Patel, M., \& Shastri, S. S. (2015). Banning tobacco sales and advertisements near educational institutions may reduce students' tobacco use risk: Evidence from Mumbai, India. Tobacco Control, 24(E1), e100-e107. https://doi.org/10.1136/tobaccocontrol-2012-050819

Notoatmodjo, S. (2012). Promosi Kesehatan dan Perilaku Kesehatan. Jakarta: Rineka Cipta, 45-62.

Notoatmodjo, S. (2016). Ilmu Perilaku Kesehatan. Jakarta: Rineka Cipta.

Nukuhehe, S. F. (2017). Pengaruh Terpaan Iklan Online Go-Jek Indonesia Terhadap Tindakan Menggunakan Jasa (Studi Pada Pengguna Go-Jek Di RT 07 / RW 07 Perumahan Bukit Cemara Tujuh). Fisipol;Universitas Muhammadiyah Malang. http://eprints.umm.ac.id/35171/

Oddo, V. M., Maehara, M., Izwardy, D., Sugihantono, A., Ali, P. B., \& Rah, J. H. (2019). Risk factors for nutritionrelated chronic disease among adults in Indonesia. PLoS One, 14(8). https://doi.org/http://dx.doi.org/10.1371/journal.pone.0221927

Pierce, J. P., Sargent, J. D., Portnoy, D. B., White, M., Noble, M., Kealey, S., Borek, N., Carusi, C., Choi, K., Green, V. R., Kaufman, A. R., Leas, E., Lewis, M. J., Margolis, K. A., Messer, K., Shi, Y., Silveira, M. L., Snyder, K., Stanton, C. A., ... Hyland, A. (2018). Association between receptivity to tobacco advertising and progression to tobacco use in youth and young adults in the PATH study. JAMA Pediatrics, 172(5), 444451. https://doi.org/10.1001/jamapediatrics.2017.5756

Prabandari, Y. S., \& Dewi, A. (2016). How do Indonesian youth perceive cigarette advertising? A cross-sectional study among Indonesian high school students. https://doi.org/10.3402/gha.v9.30914

Purnaningrum, W. D., Joebagio, H., \& Murti, B. (2017). Association Between Cigarette Advertisement, Peer Group, Parental Education, Family Income, and Pocket Money with Smoking Behavior among Adolescents in Karanganyar District, Central Java. Journal of Health Promotion and Behavior, 2(2), 150160. https://doi.org/10.26911/thejhpb.2016.02.02.05

Rachmat, M., Thaha, R. M., \& Syafar, M. (2013). Perilaku Merokok Remaja Sekolah Menengah Pertama. Jurnal Kesehatan Masyarakat Nasional, 7(11). http://journal.fkm.uia.ac.id/kesmas/article/view/363

Rizki, O., Utari, A., Kusumawati, A., \& Husodo, B. T. (2020). Pengaruh Media Sosial Terhadap Perilaku Merokok Siswa Smp Usia 12-14 Tahun Di Kota Semarang. Jurnal Kesehatan Masyarakat (Undip), 8(2), 298-303. http://ejournal3.undip.ac.id/index.php/jkm

Rukmi, S. (2019). Tobacco Use and Adolescents in Indonesia: Narrative Review of Determinants. KnE Life Sciences, 4(10), 69. https://doi.org/10.18502/kls.v4i10.3709

Syafrawati, Puri, I. Y., \& Ramadani, M. (2016). Ipteks Bagi Masyarakat Pencegahan Perilaku Merokok Pada Siswa Sekolah Dasar Di Kota Padang Tahun 2016.

TCSC IAKMI. (2018). Paparan Iklan, Promosi, dan Sponsor Rokok di Indonesia Kerjasama Tobacco Control Support Centre-Ikatan Ahli Kesehatan Masyarakat Indonesia (TCSC-IAKMI) International Union Against Tuberculosis and Lung Disease (The Union) beserta 15 universitas/organisasi. Tobacco Control 
Sport Science and Health, 3(10), 2021, 757-760

Support Centre. http://www.tcsc-indonesia.org/wp-content/uploads/2018/10/Hasil-Studi-PaparanIklan-Promosi-dan-Sponsor-Rokok-di-Indonesia_TCSC-IAKMI.pdf

Utami, D. R. R. B., \& Susilowati, T. (2019). Relationship Of Smoking Behavior Factors With Smoking Behavior Student's Of SLTPN 2 Plupuh Sragen. In IJMS-Indonesian Journal On Medical Science (Vol. 6, Issue 2). http://ejournal.ijmsbm.org/index.php/ijms/article/view/188

Wiryanatha, M. A., \& Ani, L. S. (2014). Perilaku Merokok pada Siswa Laki-laki Sekolah Menengah Pertama di Wilayah Kerja Puskesmas Sukasada II. E-Jurnal Medika Udayana, Vol 3(9), 27-36. https://ojs.unud.ac.id/index.php/eum/article/view/11861

World Health Organization. (2014). Global Youth Tobacco Survey (GYTS): Indonesia report 2014. In WhoSearo.

World Health Organization. (2019). GYTS|Global youth tobacco survey lembar informasi indonesia. https://cdn.who.int/media/docs/default-source/searo/tobacco/global-youth-tobaccosurvey/indonesia-gyts-2019-factsheet-(ages-13-15)-(draft)---revised---6-162020.pdf?sfvrsn=477996b8_2 